\title{
A Systematic Review on e-Wastage Frameworks
}

\author{
Sultan Ahmad*1, Sudan Jha ${ }^{2}$, Abubaker E.M. Eljialy ${ }^{3}$, Shakir Khan ${ }^{4}$ \\ Department of Computer Science, College of Computer Engineering and Sciences, Prince Sattam Bin Abdulaziz University \\ Alkharj, 11942, Saudi Arabia ${ }^{1}$ \\ School of Sciences, Christ (Deemed to be University), NCR, New Delhi, India ${ }^{2}$ \\ Department of Information System, College of Computer Engineering and Sciences, Prince Sattam Bin Abdulaziz University \\ Alkharj, 11942, Saudi Arabia ${ }^{3}$ \\ College of Computer and Information Sciences, Imam Mohammad Ibn Saud Islamic University (IMSIU), Riyadh, Saudi Arabia ${ }^{4}$
}

\begin{abstract}
The electronic devices that are targeted to the end users have become day to day essential parts. Traditional methodologies have changed drastically resulting in efficient mode of communication and fast information retrieval. As the demand and the production are exponentially growing, patterns of sales, storage and their destruction and then again, their collection have also been changed. This paper analyses many such behaviors of (electronic) waste management and recommends solutions like recycling management, different directives and policies required to be followed. Authors have emphasized on providing substantial information that can be useful to the regulating authorities responsible for waste management or the manufacturers of various electronic products and then the policy makers. With an extensive review of electronic wastages, authors have emphasized three variables (sales, stock and lifespan) for replacing/upgrading the older products with advanced versions. The root causes of electronic wastages are found in industrializing countries like India, China, Vietnam, Pakistan, the Philippines, Ghana and Nigeria whereas industrialized countries also play equally important role for its generation. This paper signifies the importance of e-waste management practice to reduce the emerging electronic waste hazards. Authors focus on today's demand of electronic devices, importance of e-waste management and management practices. The paper recommends key findings based on surveying data regarding the lack of regulation to manage the e-waste. The review concludes that the lack of regulation and improper awareness are the basic factors responsible for e-wastage and requires major focus to manage the e-waste.
\end{abstract}

Keywords-e-Wastage; e-Wastage management; barriers; policy; findings; e-Wastage regulations; industrializing countries; industrialized countries

\section{INTRODUCTION}

E-wastage or E-waste is a phrase, widely used to cover items of all types of electrical and electronic equipment (EEE) and its parts that have been discarded by the owner as waste without the intention of reuse. In addition, used electronics which are meant for refurbishment, reuse, recycling through material recovery, or disposal are also considered e-waste. Ewaste includes almost any household or business item containing circuitry or electrical components with either power or battery supply. To name a few, Microwaves, Fans, Refrigerators, washing machines, dryers, home entertainment devices, computers, laptops, tablets, mobile phones, Medical equipments like Dialysis Machines, Imaging Equipment, Autoclave, Defibrillator, Office and Information technology equipments like Copiers/Printers, IT Servers, Cords and Cables, WiFi dongles, switches, hubs, routers, Uninterrupted Power Supplies (UPS Systems) and other electronic utilities like Heating Pads, Remote Controls, Electrical Cords, Smart Lights, Treadmills, Smart Watches and many more. [www.ewaste1.com/what-is-e-waste/]

Few decades from now, the major proportion of e-waste was generated from the equipments that were discarded as they were no longer workable but it has been found in recent years that the current advancements in innovations in electronics and electrical technology has resulted into increasing demand for upgraded/faster/new electronic products for replacing/upgrading the older products with advanced versions. Although the exponential growth in electronics and electrical industry has benefited consumers to a great extent with massive technological advancements by making routine tasks easier and time-efficient but has also highly contributed in 'declaring' many workable electronic devices to be considered as obsolete. Thus, contributing to a great extent in generation of global electronic wastage. For instance, Video Cassette Recorder (VCR) players got replaced with Digital Versatile Disc (DVD) players and recently DVDs are being replaced by Blu-ray players. Although DVD players are working fine for normal videos but cannot showcase High-Definition (HD) videos with high quality like Blu-ray players. So, DVDs are now becoming a part of e-waste.

As there has been a sky-rocketing surge in the amount of ewaste due to dumping of electronic products by owners just because new models arrive every day especially for computers, laptops, smart phones and other electronic devices, the e-waste management has become a daunting task for both industrialized and industrializing countries. The Global Ewaste Monitor 2020 report has presented statistics related to ewaste generation from 2014 onwards. In 2014, 44.4 MT of ewaste was reported to be generated globally which has risen to 53.6 MT in 2019. The report has predicted e-waste generation to gain manifold increase by the year 2030 and estimated a shocking figure of 74.7 MT.

\section{A. Sources of e-Wastage}

Generally, the sources of e-waste comprises of almost all types of electronics and electrical equipments. But due to advancements in technology, new electronic and electrical devices are being introduced that are added up accordingly to the list of sources. So, from time to time authors have given 
different categories of devices to be considered for as sources for e-waste.

\section{B. e-Waste Management: A Global Challenge}

E-waste management refers to the disposal of electrical and electronic devices in a secured and environment friendly way. Unlike, municipal waste, e-waste requires more sophisticated techniques to be followed for management and disposal due to crucial nature of components being used in electronic and electrical devices.

Most of the electrical and electronic devices especially IT hardware contain toxic, non-biodegradable and hazardous materials including mercury, lead, cadmium, beryllium, chromium, and chemical flame retardants, or or polychlorinated biphenyls (PCBs) which have the potential to leach into soil and water as well as could be hazardous if exposed to air.

\section{Impact of E-Waste}

The outrageous increase in the amount of e-waste being generated every year across the world has put forth many challenges for industrialized and industrializing countries and has created intense pressure for the execution of sustainable practices to redesign and recycle the products.

In developed countries, several conventions, directives and laws to regulate the e-waste disposal have been formulated for efficient e-waste management which includes Basel Convention, StEP initiative, 3Rs(Reduce, Reuse and Recycle) etc. Product manufacturing industries are taking back items which are collected by retailers and local governments for safe destruction, redesign, recycle and recovery of materials. Undoubtedly, industrialized countries have gone to great lengths to formulate efficient high-cost systems to handle ewaste which includes elaborated collection systems, deployment of clean recovery technologies, carefully engineered disassembly stations, plasma furnaces to prevent release of dioxins. But, despite following various conventions, directives to protect environment from the hazardous implications of e-waste, the majority of e-waste across Europe and North America still remains unrecycled (Barba-Gutierrez et al., 2008). Therefore, to ensure proper disposal of e-waste, developed countries are shipping e-waste to developing countries like China, India, Pakistan, and Nigeria due to availability of cheap labour for recycling.

\section{LITERATURE SURVEY AND BACKGROUND STUDY}

In order to develop a conceptual framework, a systematic review of e-waste management research reported by various authors has been presented in this section. An extensive review is conducted comprising of research papers published between 2005 to 2021. A comparative analysis has been presented in the tabular form.
Both valuable metals and extraordinary materials, like $\mathrm{Pb}$, $\mathrm{Hg}$, As, Cd, Se, Cr, etc. are major factors in creating electronic wastages [1]. These non-ferrous and uncommon metals can be recuperated for additionally reuse and reuse, while the strengthened sap and epoxy sap (with generally bring down financial esteems) can be recouped for their warmth esteems through burning or reused as coatings, clearing and building materials subsequent to being powdered[2,3]. The yearly total entirety of overall EW age ranges from 20 to 50 million tons in created nations [4]. On the off chance that we allude to paper referenced at [5], the total residential electronic and electric waste is required to ascend to around 400 million units by 2015.

In 2010 Yu et.al [6] studied the existing framework for EW management in China counting regulatory policies and pilot projects. In 2012, Chibunna et. al [7], identified and talked about EW management challenges among establishments through a case study at UniversitiKebangsaan Malaysia (UKM).In 2012 Sthiannopkao and Wong [8] provided deeper knowledge about the different directives and policies needed to be followed while handling with EW. In 2013 Wang et. al [9], tried to address how to enhance EW estimates by giving techniques to increase information quality and proposed an advanced IOA method including each of the three variables (sales, stock and lifespan) and best available information focuses to prepare better datasets for modeling. In 2015 Reddy [10], concentrated upon informal EW recyclers who subsidize the environmental costs of Bangalore's IT blast. In 2016 Tansel [11], reviewed the challenges associated with increasing EWquantities. In 2016 Awasthi et. al. [12], explored the environmental contamination from EW recycling at numerous little formal and informal workshops in India. In 2017 Resmi and Fasila [13], proposed a novel calculation for establishing a standard methodology to manage and refurbish EW called EW Management and Refurbishment Prediction (EMARP), which can be adapted by refurbishing industries in order to improve their performance. Here Table I indicated the comparative analysis with advantage and disadvantages of different authors.

Both valuable metals and extraordinary materials, like $\mathrm{Pb}$, $\mathrm{Hg}, \mathrm{As}, \mathrm{Cd}, \mathrm{Se}, \mathrm{Cr}$ etc. are major factors in creating electronic wastages [14]. These non-ferrous and uncommon metals can be recuperated for additionally reuse and reuse, while the strengthened sap and epoxy sap (with generally bring down financial esteems) can be recouped for their warmth esteems through burning or reused as coatings, clearing and building materials subsequent to being powdered. The yearly total entirety of overall EW age ranges from 20 to 50 million tons in created nations [15]. On the off chance that the total residential electronic and electric waste is required to ascend to around 400 million units by 2015 . 
TABLE I. COMPARATIVE ANALYSIS

\begin{tabular}{|c|c|c|c|c|}
\hline SN & Year & Authors & Advantages & Limitations \\
\hline 1 & 2021 & $\begin{array}{l}\text { Tetiana } \\
\text { Shevchenko et. al } \\
{[16]}\end{array}$ & $\begin{array}{l}\text { Proposed a smart reverse system for e-waste management } \\
\text { based on intelligent information technology (IT) tools } \\
\text { with an aim to minimize collection costs and ultimately, } \\
\text { carbon dioxide emissions. }\end{array}$ & $\begin{array}{l}\text { - } \quad \text { The proposed smart e-waste reverse system has not } \\
\text { been tested in real life scenario. } \\
\text { - } \quad \text { Lacks real life cost - benefit analysis. }\end{array}$ \\
\hline 2 & 2020 & $\begin{array}{l}\text { Yigit Kazancoglu } \\
\text { et.al [17] }\end{array}$ & $\begin{array}{l}\text { Proposed a collection and classification framework for } \\
\text { efficient electronic wastage management by incorporating } \\
\text { data-driven technologies that would certainly ensure } \\
\text { social, environmental and economical sustainability in } \\
\text { industrializing and less industrialized nations. }\end{array}$ & $\begin{array}{l}\text { - } \quad \text { The initial cost of investment is high. } \\
\text { - } \quad \text { Absence of adequate knowledge related to data- } \\
\text { driven technologies for formulating sustainable solutions. }\end{array}$ \\
\hline 3 & 2020 & $\begin{array}{l}\text { Piotr } \\
\text { Nowakowski and } \\
\text { Teresa Pamuła } \\
\text { [18] }\end{array}$ & $\begin{array}{l}\text { Deep learning techniques have been used for categorizing } \\
\text { and measuring the size of e-waste that would aid e-waste } \\
\text { collection companies to prepare an effective collection } \\
\text { plan. }\end{array}$ & $\begin{array}{l}\text { - } \quad \text { The research is confined to Large home appliances. } \\
\text { - }\end{array}$ \\
\hline 4 & 2020 & $\begin{array}{l}\text { Sudan Jha et. al } \\
\text { [19] }\end{array}$ & $\begin{array}{l}\text { Almost all aspects of smart cities have been implemented } \\
\text { with IT enabled services. }\end{array}$ & $\begin{array}{l}\text { - Despite inclusion of smart technologies in smart } \\
\text { cities still they lack in efficient e-waste management. }\end{array}$ \\
\hline 5 & 2019 & $\begin{array}{l}\text { Charu Gangwara } \\
\text { et.al [20] }\end{array}$ & $\begin{array}{l}\text { The significant spread of cardiovascular morbidity, } \\
\text { namely hypertension, among local residents and on site } \\
\text { workers engaged in e-waste processing is explored. } \\
\text { The significant correlations between the inhabitants, } \\
\text { heavy metal concentration in the blood and corresponding } \\
\text { metal concentrations in atmosphere are identified. }\end{array}$ & $\begin{array}{l}\text { - No specific guidelines and safeguard plans have } \\
\text { been suggested. }\end{array}$ \\
\hline 6 & 2018 & $\begin{array}{l}\text { Abhishek Kumar } \\
\text { et.al [21] }\end{array}$ & $\begin{array}{l}\text { Detailed analysis of e-waste management status, } \\
\text { legislation formulated, and technology being used for e- } \\
\text { waste recycling in India. }\end{array}$ & $\begin{array}{l}\text { No specific guidelines and safeguard plans have } \\
\text { been suggested. }\end{array}$ \\
\hline 7 & 2018 & $\begin{array}{l}\text { Ashwani Kumar } \\
\text { and Gaurav } \\
\text { Dixit[22] }\end{array}$ & $\begin{array}{l}\text { Identified ' } 10 \text { barriers' that restrict efficient e-waste } \\
\text { management and used } \\
\text { interpretive structural modeling (ISM) and Decision } \\
\text { Making Trail and Evaluation Laboratory (DEMATEL) for } \\
\text { understanding the hierarchal and contextual relationship } \\
\text { among the barriers of e-waste management to aid in policy } \\
\text { and decision making. }\end{array}$ & $\begin{array}{l}\text { The proposed model is highly susceptible to } \\
\text { judgment and expertise of experts involved for framing the } \\
\text { barriers. } \\
\text { - } \\
\text { according using more barriers could be explored and validated } \\
\end{array}$ \\
\hline 8 & 2017 & $\begin{array}{l}\text { Stefan Salhofer } \\
\text { [23] }\end{array}$ & $\begin{array}{l}\text { Discussed different challenges being faced in e-waste } \\
\text { management regarding collection and treatment of e-waste } \\
\text { with an overview of technologies applied for the removal } \\
\text { of hazardous materials for the recovery of valuable } \\
\text { materials. The study focuses on three global areas, } \\
\text { namely; Europe, China and Vietnam. }\end{array}$ & $\begin{array}{l}\text { Deals with hypothetical proposal which are yet to be } \\
\text { implemented. }\end{array}$ \\
\hline 9 & 2016 & $\begin{array}{l}\text { Borthakur and } \\
\text { Govind[24] }\end{array}$ & $\begin{array}{l}\text { Studied on consumers' EW transfer behavior and } \\
\text { awareness with respect to the case of India. } \\
\text { Provides a detailed view on the current worldwide EW } \\
\text { scenarios. }\end{array}$ & $\begin{array}{ll}- & \text { Research is primary } \\
\text { - } & \text { Adequate detail. }\end{array}$ \\
\hline 10 & 2017 & Rahman[25] & $\begin{array}{l}\text { Investigated into the responsibilities of peoples played in } \\
\text { the EW management in Bangladesh and also examined the } \\
\text { existing policy gap and environmental management issues } \\
\text { in terms of EW. }\end{array}$ & $\begin{array}{l}\text { Many issues have been highlighted which is not } \\
\text { enough but need to provide solution for the issues. }\end{array}$ \\
\hline 11 & 2016 & $\begin{array}{l}\text { Debnath et. al. } \\
\text { [26] }\end{array}$ & $\begin{array}{l}\text { Tried to establish EW management as a parameter for } \\
\text { green computing. }\end{array}$ & $\begin{array}{l}\text { Various questions have been raised but did not provide any } \\
\text { solution. }\end{array}$ \\
\hline 12 & 2013 & $\begin{array}{l}\text { Dwivedy and } \\
\text { Mittal[27] }\end{array}$ & $\begin{array}{l}\text { Attempted to understand the critical elements related with } \\
\text { EW }\end{array}$ & Recycling program in the context of India \\
\hline 13 & 2013 & $\begin{array}{l}\text { Pariatamby and } \\
\text { Victor[28] }\end{array}$ & $\begin{array}{l}\text { Examined the strategically trends of EW management in } \\
\text { Asia }\end{array}$ & $\begin{array}{l}\text { Various questions have been raised but did not provide any } \\
\text { solution. }\end{array}$ \\
\hline 14 & 2015 & Jaiswal et. al. [29] & Individual awareness is addressedregarding EW handling. & Proposes a green framework for EW. \\
\hline
\end{tabular}




\begin{tabular}{|c|c|c|c|c|}
\hline 15 & 2015 & $\begin{array}{l}\text { Kumar and } \\
\text { Rawat[30] }\end{array}$ & $\begin{array}{l}\text { Analytical presentation for managing information for } \\
\text { efficient management of EW. }\end{array}$ & $\begin{array}{l}\text { It gives theoretical reasoning only. No realization on the theries } \\
\text { proposed. }\end{array}$ \\
\hline 16 & 2015 & $\begin{array}{l}\text { Davis and } \\
\text { Garb[31] }\end{array}$ & $\begin{array}{l}\text { Endeavored to give broad field employments and optional } \\
\text { written works to offer a logical order of administration } \\
\text { positions towards casual EW hones. }\end{array}$ & $\begin{array}{l}\text { The proposed method tackles a noteworthy however not } \\
\text { overwhelming portion of the puzzle } \\
\text { No other critical issues were addressed }\end{array}$ \\
\hline 17 & 2015 & $\begin{array}{l}\text { Dwivedy et. al. } \\
\text { [32] }\end{array}$ & $\begin{array}{l}\text { - Discusses on the "takeback" policies } \\
\text { - The paper was based on reasonableness for the } \\
\text { Indian conditions. }\end{array}$ & $\begin{array}{ll}- & \text { Focused on copper links in the EW stream } \\
- & \text { Discusses upstream and downstream changes } \\
- & \text { limits and business components of a formalizing } \\
\text { division } & \end{array}$ \\
\hline 18 & 2016 & Garlapati[33] & $\begin{array}{l}\text { Presented an idea of worldwide EW details, health } \\
\text { concerns of EW components alongside the waste } \\
\text { management, recycling. }\end{array}$ & $\begin{array}{l}\text { Various regulatory, regulatory bodies and their problems, and } \\
\text { corresponding suggestions, recommendations related to EW are } \\
\text { not addressed }\end{array}$ \\
\hline 19 & 2016 & Singh et. al. [34] & $\begin{array}{l}\text { Given a review of world's present CRTs squander } \\
\text { situation, to be specific extent of the request and } \\
\text { preparing, current exchange and reusing operations. }\end{array}$ & $\begin{array}{l}\text { Various questions have been raised but did not provide any } \\
\text { solution. }\end{array}$ \\
\hline 20 & 2017 & Ikhlayel[35] & Attempted to evaluate the environmental effects and & $\begin{array}{l}\text { Given a review of world's present CRTs squander situation, to } \\
\text { be specific greatness of the request and preparing, current } \\
\text { exchange and reusing operations. }\end{array}$ \\
\hline
\end{tabular}
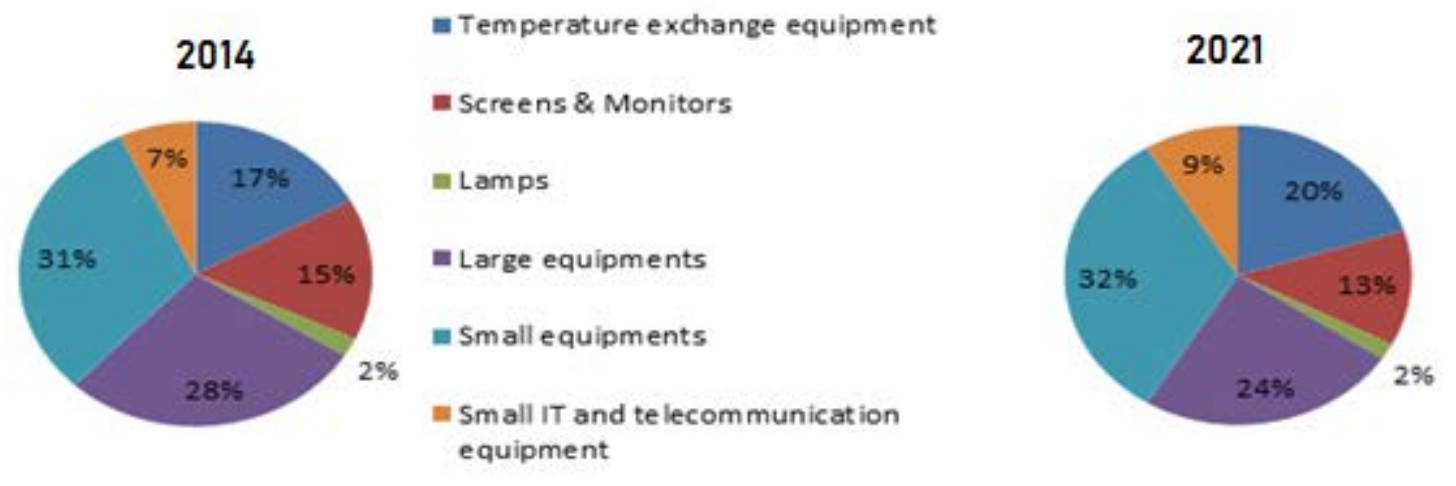

Fig. 1. Comparative Analysis of Electronic Wastages w.r.t. the Electronic Product.

TABLE II. POLLUTANTS AND THEIR RESPECTIVE COMMON SOURCES

\begin{tabular}{|l|l|}
\hline Pollutants & Sources of pollutants \\
\hline $\mathrm{As}$ & Electric diodes, Light Emitting Diodes, Semiconductors, $\mu$-waves, Solar panels \\
\hline $\mathrm{Cu}$ & Printed circuit boards, conductors, etc. \\
\hline $\mathrm{Ba}$ & Filters, insulators \\
\hline $\mathrm{Cd}$ & Cathode Ray Tubes, Cell-batteries, soldering alloys \\
\hline $\mathrm{Pb}$ & Almost all kind of transistors and batteries \\
\hline $\mathrm{Cr}$ & Hubs, Routing devices, switches, etc. \\
\hline $\mathrm{As}-$ Arsenic, Ba - Barium, Cd - Cadmium, Cr - Chromium, Co - Cobalt, Cu - Cuprum/Copper, Pb - Lead \\
\hline
\end{tabular}

In an existing framework for EW management in China counting regulatory policies are discussed along with the pilot projects. It also identified EW management challenges in Malaysia (UKM) and provided deeper knowledge about the different directives and policies needed to be followed while handling with EW and addressed how to enhance EW estimates by giving techniques to increase information quality and proposed an advanced IOA method including each of the three variables (sales, stock and lifespan) and best available information focuses to prepare better datasets for modeling. The Global E-waste Monitor 2020 concentrated upon informal
EW recyclers who subsidize the environmental costs of Bangalore's IT blast. The challenges associated with increasing EW quantities were of big concern that explored the environmental contamination from EW recycling at numerous little formal and informal workshops in India. It proposed a novel calculation for establishing a standard methodology to manage and refurbish EW called EW Management and Refurbishment Prediction (EMARP), which can be adapted by refurbishing industries in order to improve their performance.

Table I indicates the comparative analysis with advantage and disadvantages of different authors. Fig. 1 shows 
Comparative analysis of electronic wastages w.r.t. the electronic products.

The toxic substances contained in Waste Electric and Electronic Equipment (WEEE) are mostly non-degradable plastics [36]. The sources are as shown in Table II.

Apart from these, casings, PCBs, cables etc. are inevitably the most common toxics among assembled electronic devices. Firing, igniting the electronic waste materials are most commonly used today. In developing nations, these practices are done around human inhabitants or residential areas of cities. This lead to the formation of unsafe gasses which seriously damage the respiratory systems of each and every surrounding living being.

In some cases, we observe dumping these materials and landfilling which is less harmful than the preceding one. However, these may sometime become poisonous due to cyanide, lead, arsenic and mercury composition that contaminates at the out scale. Table II features the significant contaminations that cause serious health dangers when recycled improperly [37]. Separated of the few mentioned here, numerous elements pose as health risks.

\section{CHALLENGES AND OPEN ISSUES}

In this section, different challenges and issues related to ewaste management have been highlighted to seek attention of stakeholders and general public. Different initiatives and agreements have been established between post industrialized, industrialized, less industrialized and industrializing countries to save our environment and human health from the dangerous effects of e-waste. Various eco-friendly tools and techniques are being formulated for efficient disposal of e-waste with minimal environmental consequences. Moreover, various governmental and non-governmental organizations around the globe have joined hands to spread awareness among communities about e-waste management and related consequences to make them understand its need and criticality.

Despite the active participation of Governmental organizations, non-governmental organizations, industries, other stakeholders, the e-waste management is an 'open challenge' for both developed and developing countries. There are various issues that pose hindrance in the execution of systematic e-waste management strategies. Furthermore, the alarming increase in the amount of e-waste being generated around the years which is expected to reach a limit of 55 million tons in the year 2030 is really 'jaw-dropping'.

It has been observed by author in that with advancement in technologies paved way for change in composition of electronic and electric devices. So, the traditional recycling and disposal e-waste techniques are no longer applicable for the extraction of constituent elements. In Fig. 2 below, change in composition of Personal computers (PCs) over the time has been depicted. In earlier PCs, mainly three constituent elements were present like glass, plastic and metals but in recent PCs, we could varied elements like Zinc, Lead, Iron, Aluminium, Copper, etc.

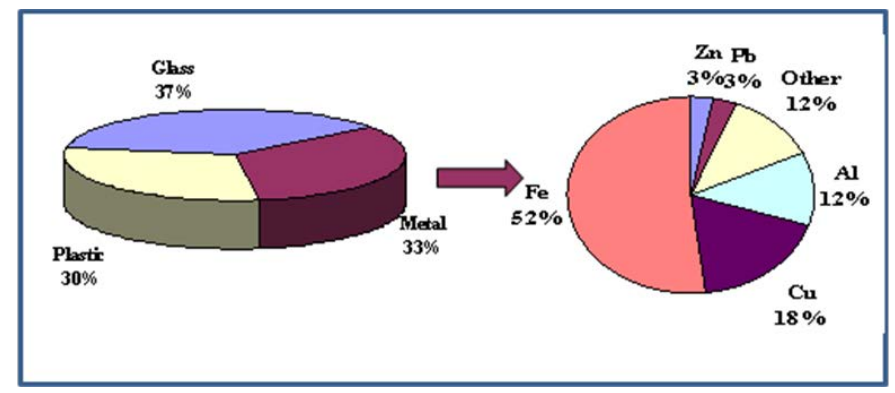

Fig. 2. Change in Composition of Personal Computers.

Therefore, it is evident that e-waste recycling and disposal methodologies need to revised and reformulated for the inclusion of changing composition of e-waste.

\section{A. Switching to Transboundary Shipment}

The management of e-waste in developing and transition countries is getting worse day by day. The major factors responsible for this are.

1) Illegal trafficking of waste materials

2) Unauthorized recycling of e-waste

3) Lack of skilled man power

4) No regulatory rules and regulations / protocols flourished for stakeholders and institutions that are involved in e-waste management.

It has become a normal trend that (a) the large amount of ewaste generated from developed countries are exported to developing countries or (b) those discarded by developing countries, are rapidly taken up by transition countries; and this has resulted into a very high impact on emerging economies of these countries.

\section{B. International Treaties}

One such example is Basel Convention in which it has been reported that.

- Only $20 \%$ of the global electronic wastage are recycled every year; i.e. $40 \mathrm{Mt}$ electronic wastages are burned or destroyed or illegally traded. Further, 50\% of these wastages consist of handheld devices and TVs along with household appliances.

- The rate of e-waste generated in emerging economies like India and China is increasing from 5\% to $10 \%$ annually. These data do not include the imported electronic wastages whether they are legal or illegal.

- The first country in the world where e-waste management system was formally established is Switzerland where $11 \mathrm{~kg} /$ capita of e-waste are recycled. Their policy targets $4 \mathrm{~kg} /$ capita as regulated by the European Union (EU).

\section{INTEROPERABILITY OF ELECTRONIC WASTAGES}

In this section, we characterize e-waste by investigating its criticality. The reuse of EW, state enactment, and the issue of the worldwide shipment of risky e-wastages are also adhered. Various hazardous development in the hardware business has prompted a quick raising issue of end-of-life (EOL) gadgets or 
e-squander. Squandering of electronic is growing thus resulting in a high surge for the requirement of powerful hardware reusing programs.

It is assessed that $75 \%$ of electronic things are secured in view of defenselessness of how to supervise it. These electronic hurls out lie unattended in houses, work environments, dissemination focuses et cetera and regularly mixed with family wastes, which are at last orchestrated off at landfills. This requires implementable organization measures. In wanders organization of EW should begin at the explanation behind age. This should be possible by waste minimization methodologies and by supportable thing design. Waste minimization in endeavors incorporates getting a handle on:

1) Inventory organization.

2) Changing the production-process.

3) Volume reduction.

4) Recovery and reuse.

Challenges of EW Recycling: The toxic substances contained in Waste Electric and Electronic Equipment (WEEE) are mostly non-degradable plastics. The sources are as shown in Table III. Apart from these, casings, PCBs, cables etc. are inevitably the most common toxics among assembled electronic devices.

Firing, igniting the electronic waste materials are most commonly used today. In developing nations, these practices are done around human inhabitants or residential areas of cities. This lead to the formation of unsafe gasses which seriously damage the respiratory systems of each and every surrounding living being.

TABLE III. POLLUTANTS AND THEIR RESPECTIVE COMMON SOURCES

\begin{tabular}{|l|l|}
\hline Pollutants & Sources of pollutants \\
\hline $\mathrm{As}$ & $\begin{array}{l}\text { Electric diodes, Light Emitting Diodes, } \\
\text { Semiconductors, } \mu \text {-waves, Solar panels }\end{array}$ \\
\hline $\mathrm{Cu}$ & Printed circuit boards, conductors, etc. \\
\hline $\mathrm{Ba}$ & Filters, insulators \\
\hline $\mathrm{Cd}$ & Cathode Ray Tubes, Cell-batteries, soldering alloys \\
\hline $\mathrm{Pb}$ & Almost all kind of transistors and batteries \\
\hline $\mathrm{Cr}$ & Hubs, Routing devices, switches, etc. \\
\hline
\end{tabular}

As - Arsenic, Ba - Barium, Cd - Cadmium, Cr Chromium, $\mathrm{Co}$ - Cobalt, $\mathrm{Cu}$ - Cuprum/Copper, $\mathrm{Pb}$ - Lead

TABLE IV. MAJOR POLLUTANTS AND THEIR EFFECTS OF HEALTH

\begin{tabular}{|c|c|}
\hline Pollutants & Major organic attack \\
\hline Lead & - $\quad$ Psychological degradation \\
\hline Plastics & - $\quad$ Respiratory organs damage \\
\hline Cadmium & $\begin{array}{cl}\text { Affecting } & \\
- & \text { bones and joints } \\
- & \text { digestive systems }\end{array}$ \\
\hline $\begin{array}{l}\text { Acid } \\
\text { Leachates }\end{array}$ & $\begin{array}{ll}\text { - } & \text { Respiratory issues } \\
\text { - } & \text { Eye infection } \\
\text { - } & \text { Skin erosion }\end{array}$ \\
\hline
\end{tabular}

In some cases, we observe dumping these materials and landfilling which is less harmful than the preceding one. However, these may sometime become poisonous due to cyanide, lead, arsenic and mercury composition that contaminates at the out scale. Table IV features the significant contaminations that cause serious health dangers when recycled improperly. Separated of the few mentioned here, numerous elements pose as health risks.

Waste Electric and Electronic Equipment (WEEE) or EW joins a wide and growing collection of electronic devices going from tremendous family unit contraptions, for example, coolers, ventilation systems, PDAs, singular stereos, and buyer equipment to PCs disposed by the customers. These equipment needs to be well treated, mostly mercury, chromium, arsenic, lead, cadmium, and plastics responsible for various toxics.

\section{SCHEMATIC FRAMEWORKS FOR E-WASTAGES PRACTICED TILl DATE}

The electronic wastage has been practiced in a smaller note in most of the countries. Table III justifies this statement. The countries adhering to their policies also aren't able to implement the same as per the expectation. Fig. 3 is a schematic (conceptual) framework carried out based on the rigorous survey and relevant literature done by the authors. This clearly indicates that there are some of the unorganized sectors seem to be active in many regions. Due to the lack of proper policy, the authorities are not in a position to give the proper regulatory actions to be taken in care of these wastages. Even it is very disappointing to note that there is no reliable source available that can state about (a) the total number of organizations involved in such activities and (b) amount of ewaste that is recycled by the concerned dominants.

Descriptive analysis of our review work includes central tendency, mean and variation of variables of the study (See Fig. 1). Each of the variables are segregated into 24 aptitude questions.

\section{A. Political or Regulating Factors (PRF)}

The PRFs are analyzed based on four measuring questionnaires. EW

PRF1 - The degree of governments' initiation in managing

\section{PRF2 - Properness of policy for EW Management.}

PRF3 - Consciousness among of international community in EW management, and

PRF4 - Degree of following the international practices to handle the E-Waste

Fig. 4 depicts the bar diagrammatic view of PRF1, PRF2, PRF3 and PRF4. This clearly indicates the lack of significant policies for EW management. Proper policy helps to manage the e-waste in effective ways that is generating every year. 


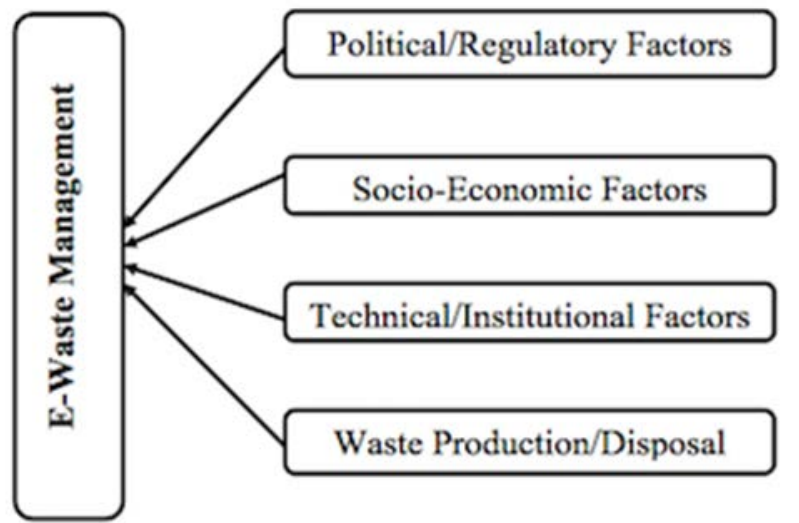

Fig. 3. Theoretical Framework of E-Waste.

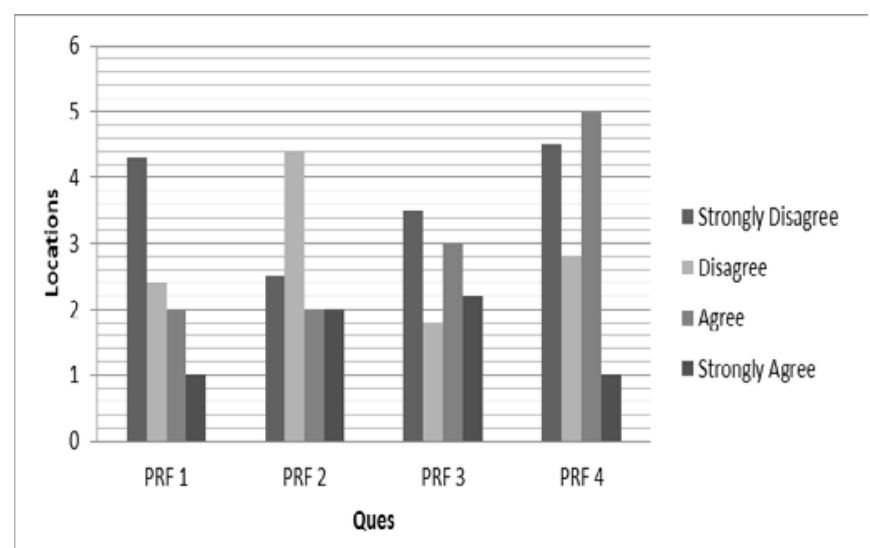

Fig. 4. Political/Regular Factor.

\section{B. Waste Production/Disposal (WPD)}

Four different questionnaires were been floored to analyze the effect of waste Production and Disposal.

WPD1 - referred to the scale at which the EW are generated on daily basis,

WPD2 - referred to the rate at which the electric or electronic equipment were discarded or donated per person,

WPD3 - referred to the status of discarded electric or electronic equipment - whether they are thrown away cumulating other waste, and

WPD4 - if those discarded or disposed electric and electronic equipment had any hazardous parts and that if any special method for safety disposal were applied.

Fig. 5 can be concluded with respondents' response that a special procedure is required utmost for disposal of electronic wastages. Due to the advanced technology, every year many electronics items are being produced and side by side every year electronics items are getting damaged and e-waste are produced. In developing countries, there is no advanced technology to manage this e-waste; i.e. damaged items are not disposed properly.

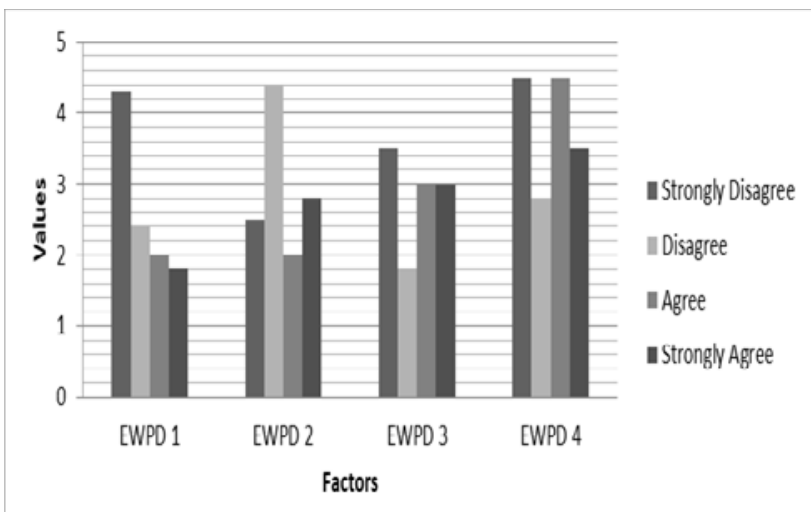

Fig. 5. Waste Production/Disposal.

\section{E-Waste Management (EWM)}

The four different questionnaires polled for EW management were as below:

EWM1 - awareness about EW management,

EWM2 - necessity of EW collector

EWM3 - convenience of the existing method for EW, and

EWM4 - accessibility of information regarding EW management.

Based on above queries, Fig. 5 is schematized. Fig. 5 depicts electronic wastage collector is the need of the hour which will ease the process of disposal. It will also reduce / resolve the confusion regarding purpose of e-waste.

\section{FINDINGS AND RECOMMENDATIONS}

We have performed a rigorous review on electronic wastages. The reviews were based on five main factors. They are (a) Political / Regulating, (b) Social-Economic, (c) Technical / Institutional, (d) Waste Production / Disposal and (e) EW Management factors were examined. Based on analysis and various literature survey, the findings are listed as below:

1) Lack of regulatory body in tracing and handling EW

2) Lack of Solid governmental policies to tackle EW

3) Managing electronic wastes

a) from house hold, and

b) work-places

4) Reusability and finding out the possibility of reusable of these components or EW for future use without affecting any of the other factors

5) Regular updates regarding the current (and past) status of EW of various EEE

6) Finding out the correct sources that are responsible for EW

7) Assessing the barriers of EW management.

The survey was conducted among 151 individuals who were "understood as aware of EW" and data were collected in physical form. These individuals were categorized as individual working in technology related companies; electrical 
or electronic (or both) shops; the individual working in handling the e-waste management. Out of 151 individuals, 61 females and 90 males comprising the percentage of $40.4 \%$ and $59.6 \%$, respectively.

In addition to age, there are $37.7 \%$ of respondents who fall under the age group below 25 years, $56.3 \%$ respondents are aged 26-35 years, 2.6\% respondents are of age group 36-45 years and $3.4 \%$ of respondents are of age group of 46 and 55 above year. $23.1 \%$ of respondent are student, $42 \%$ of respondents are Service holders, $11.9 \%$ of respondent are selfemployed (Business) and, $22 \%$ of respondent are engaged in other professions.

Based on the survey, data and findings indicated above, authors propose the recommendations as below:

1) Awareness / consciousness regarding managing $\mathrm{EW}$ is mandatory. There is a very less human resource working for EW, their efforts and activities need to be maximized one of which may be done through promotional activity.

2) It is well understood that the growth of generation of EW is exponential. Advanced technology as perturbed by UN (2014) should be availed specially to developing countries.

3) EW collector needs to avail to each sector for the EWaste Management.

4) Technical manpower to be produced by the authorized body by providing related technical knowledge and thus generating skilled manpower in EW management.

5) The rapid advancement in ICT has result in improve capacity in computing devices but simultaneously decreases in the product lifetime as a result the generation of EEE components are growing rapidly. A concrete policy and budget in e-waste management should be allotted.

\section{CONCLUSION}

Electric and electronic wastages can result into an environmental disaster. An analytical study was done regarding EW and it was found that despite of consciousness, and awareness about these kind of wastages, appropriate measures are still not initiated for proper monitoring, mitigating and managing the EW scientifically. Sources responsible for creating electric and electronic wastages were also discussed. No authorized sectors have been officially designated for the same in most of the developing countries which is the need of the hour. Therefore, this paper focuses on the importance of ewaste management and its management practice and identifies some key findings along with recommendations based on various socio-tech factors. Based on surveying data, the paper concludes that lack of regulation regarding e-waste is the major concern to manage the e-waste.

\section{FUTURE WORK}

To measure the reliability of this study, Cronbach's alpha will be used after the collection of data from wide sectors and a significant procedural conceptual model will be proposed.

\section{ACKNOWLEDGMENT}

We thank the Deanship of Scientific Research, Prince Sattam Bin Abdulaziz University, Alkharj, Saudi Arabia for help and support.

\section{REFERENCES}

[1] Chancerel, P.; Meskers, C.E.M.; Hagelüken, C.; Rotter, V.S. Assessment of Precious Metal Flows During Preprocessing of Waste Electrical and Electronic Equipment. Journal of Industrial Ecology2009, 13, 791-810, doi:10.1111/j.1530-9290.2009.00171.x.

[2] Widmer, R.; H, O.-K. Global perspectives on e-waste. Environ Impact Assess Rev2005, 25.

[3] Zhou, L.; Xu, Z.M. Research progress of recycling technology for waste electrical and electronic equipment. Mater Rev2012, 26.

[4] Schwarzer, S.; AD, B. E-waste, the hidden side of IT equipment's manufacturing and use. UNEP Early Warning on Emerging Environmental Threats2005.

[5] Eugster, M.; Duan, H.B.; JH, L. Sustainable electronics and electrical equipment for China and the world. International Institute for Sustainable Development2008.

[6] Yu, J.; Williams, E.; Ju, M.; Shao, C. Managing e-waste in China: Policies, pilot projects and alternative approaches. Resources, Conservation and Recycling2010, 54, 991-999.

[7] Chibunna, J.B.; Siwar, C.; Begum, R.A.; Mohamed, A.F. The challenges of e-waste management among institutions: A case study of UKM. Procedia-Social and Behavioral Sciences2012, 59, 644-649.

[8] Sthiannopkao, S.; Wong, M.H. Handling e-waste in developed and developing countries: Initiatives, practices, and consequences. Science of the Total Environment2013, 463, 1147-1153.

[9] Wang, F.; Huisman, J.; Stevels, A.; Baldé, C.P. Enhancing e-waste estimates: Improving data quality by multivariate Input-Output Analysis. Waste Management2013, 33, 2397-2407, doi:10.1016/j.wasman.2013.07.005.

[10] Reddy, R.N. Producing abjection: E-waste improvement schemes and informal recyclers of Bangalore. Geoforum2015, 62, 166-174.

[11] Tansel, B. From electronic consumer products to e-wastes: Global outlook, waste quantities, recycling challenges. Environment international2017, 98, 35-45.

[12] Awasthi, A.K.; Zeng, X.; Li, J. Environmental pollution of electronic waste recycling in India: A critical review. Environmental pollution2016, 211, 259-270.

[13] Resmi, N.G.; Fasila, K.A. E-waste Management and Refurbishment Prediction (EMARP) Model for Refurbishment Industries. Journal of Environmental Management2017, 201, 303-308, doi:10.1016/j.jenvman.2017.06.065.

[14] Gangwar C, Choudhari R, Chauhan A, Kumar A, Singh A, Tripathi A. Assessment of air pollution caused by illegal e-waste burning to evaluate the human health risk. Environment international. 2019 Apr 1;125:1919.

[15] Mohammed Yousuf Uddin, Sultan Ahmad and Mohammad Mazhar Afzal, "Disposable Virtual Machines and Challenges to Digital Forensics Investigation” International Journal of Advanced Computer Science and Applications(IJACSA), 12(2), 2021. http://dx.doi.org/10.14569/IJACSA.2021.0120299.

[16] Shevchenko, Tetiana, Michael Saidani, Yuriy Danko, Ievgeniia Golysheva, Jana Chovancová, and Roman Vavrek. 2021. "Towards a Smart E-Waste System Utilizing Supply Chain Participants and Interactive Online Maps" Recycling 6, no. 1: 8. https://doi.org/10.3390/recycling6010008.

[17] Kazancoglu Y, Ozbiltekin M, Ozen YD, Sagnak M. A proposed sustainable and digital collection and classification center model to manage e-waste in emerging economies. Journal of Enterprise Information Management. 2020 Jun 19.

[18] Nowakowski P, Pamuła T. Application of deep learning object classifier to improve e-waste collection planning. Waste Management. 2020 May 15;109:1-9. 
[19] Jha S, Nkenyereye L, Joshi GP, Yang E. Mitigating and monitoring smart city using internet of things. Computers, Materials \& Continua. 2020 Jan 1;65(2):1059-79.

[20] Gangwar C, Choudhari R, Chauhan A, Kumar A, Singh A, Tripathi A. Assessment of air pollution caused by illegal e-waste burning to evaluate the human health risk. Environment international. 2019 Apr 1;125:1919.

[21] Kumar, A., Choudhary, V., Khanna, R. et al. Recycling polymeric waste from electronic and automotive sectors into value added products. Front. Environ. Sci. Eng. 11, 4 (2017). https://doi.org/10.1007/s11783-0170991-x.

[22] Kumar A, Dixit G. An analysis of barriers affecting the implementation of e-waste management practices in India: A novel ISM-DEMATEL approach. Sustainable Production and Consumption. 2018 Apr 1;14:3652.

[23] Salhofer S, Obersteiner G, Schneider F, Lebersorger S. Potentials for the prevention of municipal solid waste. Waste management. 2008 Jan 1;28(2):245-59.

[24] Borthakur, A.; Govind, M. Emerging trends in consumers' E-waste disposalbehaviour and awareness: A worldwide overview with special focus on India."Resources. Conservation and Recycling2017, 117, 102113.

[25] Rahman, M.A. E waste management: A study on legal framework and institutional preparedness in Bangladesh. Thesis, North South University: Bangladesh, 2016.

[26] Debnath, B.; Roychoudhuri, R.; Ghosh, S.K. E-Waste Management-A Potential Route to Green Computing. Procedia Environmental Sciences2016, 35, 669-675.

[27] Dwivedy, M.; Mittal, R.K. Willingness of residents to participate in ewaste recycling in India. Environmental Development2013, 6, 48-68.
[28] Pariatamby, A.; Victor, D. Policy trends of e-waste management in Asia. Journal of Material Cycles and Waste Management2013, 15, 411-419.

[29] Jaiswal, A.; Samuel, C.; Patel, B.S.; Kumar, M. Go green with WEEE: Eco-friendly approach for handling e-waste. Procedia Computer Science2015, 46, 1317-1324.

[30] Kumar, S.; Rawat, S. Future e-Waste: Standardisation for reliable assessment. Government Information Quarterly2018, 35, S33-S42, doi:10.1016/j.giq.2015.11.006.

[31] Davis, J.M.; Garb, Y. A model for partnering with the informal e-waste industry: rationale, principles and a case study. Resources, Conservation and Recycling2015, 105, 73-83.

[32] Dwivedy, M.; Suchde, P.; Mittal, R.K. Modeling and assessment of ewaste take-back strategies in India. Resources, Conservation and Recycling2015, 96, 11-18.

[33] Garlapati, V.K. E-waste in India and developed countries: Management, recycling, business and biotechnological initiatives. Renewable and Sustainable Energy Reviews2016, 54, 874-881.

[34] Singh, N.; Li, J.H.; Zeng, X.L. Global responses for recycling waste CRTs in ewaste. Waste Management2016, 57, 187-197.

[35] Ikhlayel, M. Environmental impacts and benefits of state-of-the-art technologies for E-waste management. Waste Management2017, 68, 458-474.

[36] Sepúlveda, A. A review of the environmental fate and effects of hazardous substances released from electrical and electronicequipment during recycling: Examples from China and India. Environmental Impact Assessment Review2010, 30, 28-41.

[37] Janz, A.; Bilitewski, B. Hazardous substances in waste electrical and electronic equipment' in RakeshJohri, E-waste:Implications, Regulations and management in India and current global best practices; TERI, New, 2008. 